\title{
Frequencies of HER-2/neu expression and gene amplification in patients with oesophageal squamous cell carcinoma
}

\author{
K Mimura', K Kono*,1, M Hanawa², F Mitsui' ${ }^{1,2}$, H Sugai', N Miyagawa', A Ooi' ${ }^{2}$ and H Fujii' \\ 'First Department of Surgery, University of Yamanashi, I I 0 Tamaho, Yamanashi 409-3898, Japan; ${ }^{2}$ First Department of Pathology, University of \\ Yamanashi, Yamanashi 409-3898, Japan
}

\begin{abstract}
The utilisation of antitumour T cells induced by cancer vaccination with HER-2 peptides or antibodies (Herceptin) against HER-2, as immunotherapy for oesophageal cancer, is a novel and attractive approach. It is important to clarify the frequencies of HER-2 expression and gene amplification in patients with oesophageal squamous cell carcinoma (SCC) and to evaluate the relationship between HER-2 status and HLA haplotype, since the candidates for HER-2 peptide-based vaccination are restricted to a certain HLA haplotype. We determined the frequency of HER-2 expression using the HercepTest ${ }^{\mathrm{TM}}$ for immunohistochemistry and HER-2 gene amplification by fluorescence in situ hybridisation (FISH) assay in oesophageal SCC $(n=66)$. HER-2-positive tumours $(I+/ 2+/ 3+)$ analysed by a HercepTest were observed in $30.3 \%$ of all the patients and HER-2 gene amplification evaluated by FISH was observed in $11.0 \%$ of all the patients, in which all HercepTest $(3+)$ tumours were found to have gene amplification and three of six moderately positive $(2+)$ tumours showed gene amplification. Furthermore, HER-2-positive cells were present more diffusely and were larger within each tumour in the patients who were HercepTest $3+$ than those who were HercepTest I + . Moreover, the survival rate in HER-2-positive group was significantly worse than that in HER-2-negative group. Also, the survival rate in the patients with HER-2 gene amplification was significantly worse than that without HER-2 gene amplification. In addition, oesophageal SCC patients with both HLA-A24-positive and HER-2-positive tumours $(1+/ 2+13+)$ accounted for $26 \%$ of these cases, and both HLA-A2- and HER-2-positive tumours accounted for $18 \%$ of them.

British Journal of Cancer (2005) 92, I253- 1260. doi: I0.1038/sj.bjc.6602499 www.bjcancer.com

Published online 22 March 2005

(c) 2005 Cancer Research UK
\end{abstract}

Keywords: HER-2/neu; FISH; immunohistochemistry; HLA; immunotherapy

While most patients with oesophageal cancer in Western countries have adenocarcinoma, most of those in Japan have squamous cell carcinoma (SCC). Despite various treatments such as surgical resection with extensive lymphadenectomy (Maillet et al, 1982; Altorki and Skinner, 1990; Kato et al, 1991; Akiyama et al, 1994) and the surgery combined with chemotherapy (Hayashi et al, 2001) and/or radiotherapy (Le Prise et al, 1995; Adham et al, 2000; Ishikura et al, 2003), the prognosis for advanced patients with oesophageal SCC remains poor. The utilisation of antitumour $\mathrm{T}$ cells or antibodies against tumour antigens, as immunoadjuvant therapy for oesophageal SCC, is therefore an attractive approach.

The HER-2/neu (designated as HER-2) proto-oncogene located on chromosome 17(17q12-q21.32) (Popescu et al, 1989) encodes a $185-\mathrm{kDa}$ transmembrane glycoprotein with tyrosine-specific kinase activity (Coussens et al, 1985). The HER-2 proto-oncogene is amplified and overexpressed in approximately $30 \%$ of human ovarian and breast tumours (Slamon et al, 1989), and in $8.2 \%$ of gastric cancers (Takehana et al, 2002). The humanised monoclonal antibody (mAb) Herceptin, which specifically targets HER-2, exhibits potent growth inhibitory activity against HER-2-over expressing tumours (Sliwkowski et al, 1999). Herceptin has

*Correspondence: Dr K Kono; E-mail: kojikono@yamanashi.ac.jp Received 26 October 2004; revised 26 January 2005; accepted 8 February 2005; published online 22 March 2005 boosted the interest of clinicians in immunotherapy based on this molecule as it represents the first mAb approved for therapeutic use with proved survival benefit in patients with HER-2-positive breast cancer with metastasis (Baselga et al, 1996; Slamon et al, 2001). Moreover, abundant examples from experimental models and clinical trials suggest that HER-2 can be immunogenic and generate antibodies, CTL- and helper T-cell-specific responses in individuals with HER-2-overexpressing tumours (Fisk et al, 1995; Kono et al, 1998). Based on the above reports, anti-HER-2 immune targeting could be utilised as an attractive approach to treat oesophageal cancer. Thus, it is important to clarify the frequency of HER-2 expression and gene amplification relating to the HLA haplotype in order to determine possible candidates for HER-2based immunotherapy, since the candidates for HER-2 peptidebased vaccination are restricted to a certain HLA haplotype.

With respect to oesophageal SCC, the frequencies of HER-2 overexpression analysed by immunohistochemistry (IHC) ranged from 0 to $55.9 \%$ (Mori et al, 1987; Chang et al, 1992; Suo et al, 1992; Shiga et al, 1993; Suwanagool et al, 1993; Suo et al, 1995; Hardwick et al, 1997; Lam et al, 1998; Akamatsu et al, 2003). Furthermore, reports describing HER-2 gene amplification ranged from 0 to $25 \%$, and these studies were performed by Northern blot, slot blot or RT - PCR analysis (Shiga et al, 1993; Ikeda et al, 1996; Tanaka et al, 1997; Friess et al, 1999). The discrepancy in the HER2 frequencies among the reports may be related to the methodology, including the different mAbs used in IHC or 
inaccurate analysis for gene amplification. There has been no previous report describing HER-2 gene amplification in oesophageal SCC analysed by fluorescence in situ hybridisation (FISH) analysis.

In the present study, we determined the exact frequency of HER2 abnormalities using the HercepTest ${ }^{\mathrm{TM}}$ for IHC and the PathVysion test for FISH in oesophageal SCC, and analysed patient's data for the survival rate. Both the HercepTest and the PathVysion FISH assay are approved by the US Food and Drug Administration (FDA) for determining the eligibility for Herceptin treatment in breast carcinoma. Furthermore, we have evaluated a possible candidate for anti-HER-2 immune targeting therapy for oesophageal SCC.

\section{MATERIALS AND METHODS}

\section{Patients and samples}

In all, 66 consecutive patients with primary oesophageal SCC who were histologically diagnosed and treated in the First Department of Surgery, University of Yamanashi Hospital, between 1998 and 1999, were enrolled in the present study and all the patients were followed up for 5 years. None of the patients had received any treatment before surgery (preoperative radiotherapy or chemotherapy) and all patients had undergone oesophagectomy with two-field $(n=39)$ or three-field $(n=27)$ lymph node dissection. The patients were classified using the tumour node metastasis (TNM) classification. The characteristics of the patients are shown in Table 1. The study was approved by the ethical committee of University of Yamanashi and written informed consent was obtained from all individuals.

Formalin-fixed, paraffin-embedded tissue blocks were used for IHC and FISH analysis.

\section{HLA class I typing}

Heparinised peripheral blood was obtained from patients prior to the operation. Peripheral blood lymphocytes (PBLs) were purified by centrifugation on a Ficoll gradient (Pharmacia, Uppsala, Sweden). For class I typing, PBLs were subjected to a complement-dependent microcytotoxicity assay using antisera to HLA-A loci. Peripheral blood lymphocytes were typed for A loci 1, 2, 3, 9, $10,11,19,23,24,25,26,28,29,30,31,32,33,34,36,43,66,68,69$ and 74 .

\section{IHC analysis}

Immunohistochemical staining was performed using the HercepTest $^{\mathrm{TM}}$ (DaKoCytomation, Denmark) according to the manufacturer's recommendations. Archival, formalin-fixed, paraffinembedded material was used to obtain $4-\mu$ m-thick sections from the main tumour and the regional lymph nodes. Briefly, deparaffinised and rehydrated tissue sections were incubated with the Epitope Retrieval Solution in a heat water bath for $40 \mathrm{~min}$ at $95-99^{\circ} \mathrm{C}$. Then, the sections were cooled at room temperature for $20 \mathrm{~min}$ and washed with TRIS buffer for $5 \mathrm{~min}$. Next, endogenous peroxidase was blocked with $3 \%$ hydrogen peroxide for $5 \mathrm{~min}$. The primary antibody was a rabbit polyclonal antibody to human HER2 , which recognises an intracytoplasmic part of HER-2, and the primary negative control antibody was an immunoglobulin fraction of normal rabbit serum at an equivalent protein concentration as the antibody to HER-2. The sections were washed with a TRIS buffer for $5 \mathrm{~min}$ and incubated with the primary antibody or the primary negative control antibody at room temperature for $30 \mathrm{~min}$. After rewashing with a TRIS buffer for $5 \mathrm{~min} \times 2$ times, the primary antibody was detected using the Visualisation Reagents, which were a dextran polymer conjugated with horseradish peroxidase and affinity-isolated goat anti-rabbit
Table I Clinical features of the patients $(n=66)$

\begin{tabular}{|c|c|}
\hline $\begin{array}{l}\text { Age (years old) } \\
\text { Mean } \\
\text { Range }\end{array}$ & $\begin{aligned} & 65.3 \\
& 45-81\end{aligned}$ \\
\hline $\begin{array}{l}\text { Gender } \\
\text { Male } \\
\text { Female }\end{array}$ & $\begin{array}{r}62 \\
4\end{array}$ \\
\hline $\begin{array}{l}\text { Primary tumour }{ }^{\mathrm{a}} \\
\text { PTis } \\
\text { PTIa } \\
\text { PTIb } \\
\text { PT2 } \\
\text { PT3 }\end{array}$ & $\begin{array}{r}2 \\
8 \\
18 \\
5 \\
32\end{array}$ \\
\hline $\begin{array}{l}\text { LNM } \\
\text { Negative } \\
\text { Positive }\end{array}$ & $\begin{array}{l}29 \\
37\end{array}$ \\
\hline $\begin{array}{l}\text { SCC differentiation } \\
\text { Well differentiated } \\
\text { Moderate differentiated } \\
\text { Poorly differentiated }\end{array}$ & $\begin{array}{l}15 \\
35 \\
14\end{array}$ \\
\hline $\begin{array}{c}\text { Stage } \\
0 \\
\text { I } \\
\text { II } \\
\text { III } \\
\text { Iva } \\
\text { Ivb }\end{array}$ & $\begin{array}{r}9 \\
5 \\
25 \\
19 \\
6 \\
1\end{array}$ \\
\hline
\end{tabular}

$\mathrm{LNM}=$ lymph node metastasis; $\mathrm{SCC}=$ squamous cell carcinoma. ${ }^{\text {a }}$ The grade of tumour and stages were defined according to the UICC (TMN) classification.

immunoglobulins, for $30 \mathrm{~min}$ of incubation at room temperature. Subsequently, following rewashing with TRIS buffer for $5 \mathrm{~min} \times 2$ times, diaminobenzidine was added as a visualisation reagent for $10 \mathrm{~min}$ and the section was counterstained with haematoxylin. Control slides provided with the HercepTest ${ }^{\mathrm{TM}}$ kit, which contained three human breast cancer cell lines with staining intensity scores of $0,1+$ and $3+$, were used in the present study. IHC analysis was performed by two observers ( $\mathrm{KM}$ and $\mathrm{KK}$ ) according to the staining intensity scores provided by the HercepTest ${ }^{\mathrm{TM}}$ kit. Each section was classified into four categories $(0,1+, 2+, 3+)$, in which tumour cells with complete absence of staining were scored as 0 , those with incomplete membranous staining were classified as $1+$, those with moderate, complete membranous staining were classified as $2+$ and those with strong, complete membranous staining were classified as $3+$ (Figure 1).

Furthermore, we evaluated the immunostaining pattern into two patterns, spot type or diffuse type (Figure 2), in which the diffuse type indicated tumour cells with membranous staining spread throughout the tumour tissue continuously. On the other hand, the spot type indicated tumour cells with membranous staining on one part or several parts separately in the section.

\section{FISH analysis}

FISH analysis was performed using the PathVysion ${ }^{\circledR}$ HER-2 DNA Probe Kit (VYSIS, Downers Grove, IL, USA). The HER-2/neuSpectrumOrange probe is specific for the HER-2 gene locus (17q11.2-q12). The CEP 17 (chromosome enumeration probe)/ SpectrumGreen probe is specific for the alpha-satellite DNA sequence (centromere region of chromosome 17). To determine the copy number for chromosome 17, we used CEP 17 as the control. FISH procedures were conducted according to the manufacturer's guidelines, except the removal of the protein from 

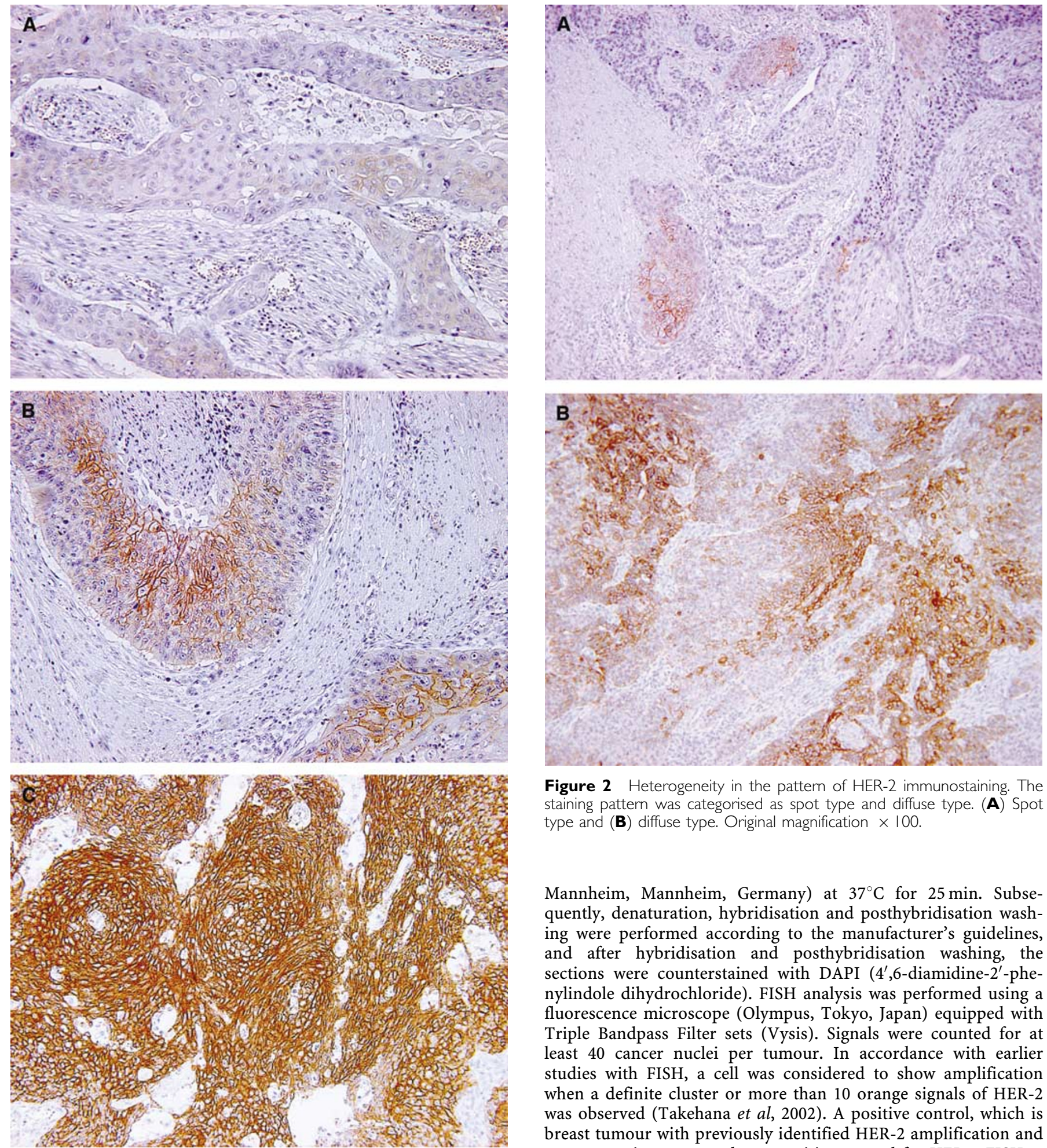

Figure 2 Heterogeneity in the pattern of HER-2 immunostaining. The staining pattern was categorised as spot type and diffuse type. (A) Spot type and $(\mathbf{B})$ diffuse type. Original magnification $\times 100$.

Mannheim, Mannheim, Germany) at $37^{\circ} \mathrm{C}$ for $25 \mathrm{~min}$. Subsequently, denaturation, hybridisation and posthybridisation washing were performed according to the manufacturer's guidelines, and after hybridisation and posthybridisation washing, the sections were counterstained with DAPI $\left(4^{\prime}, 6\right.$-diamidine- $2^{\prime}$-phenylindole dihydrochloride). FISH analysis was performed using a fluorescence microscope (Olympus, Tokyo, Japan) equipped with Triple Bandpass Filter sets (Vysis). Signals were counted for at least 40 cancer nuclei per tumour. In accordance with earlier studies with FISH, a cell was considered to show amplification when a definite cluster or more than 10 orange signals of HER-2 was observed (Takehana et al, 2002). A positive control, which is breast tumour with previously identified HER-2 amplification and overexpression, was used as a positive control for HER-2 FISH.

Figure I Representative immunostaining of HER-2-positive cells. (A) $1+$ staining cases, $(\mathbf{B}) 2+$ staining cases and $(\mathbf{C}) 3+$ staining cases. Original magnification $\times 200$.

the section where we used our own protocol as described previously (Takehana et al, 2002). Briefly, sections were deparaffinised, dehydrated and incubated in $20 \%$ sodium bisulphate/ $2 \times$ standard saline citrate at $43^{\circ} \mathrm{C}$ for $20 \mathrm{~min}$. Sections were washed with SCC and treated with proteinase $\mathrm{K}$ (Boehringer-

\section{Statistical analysis}

The $\chi^{2}$ test was applied to examine the differences in frequencies of the HLA-A haplotype and HER-2 expression in oesophageal SCC, the differences in HercepTest score and the rate of HER-2-positive cells in each tumour, and the differences in the lymph node metastasis of HER-2-positive patients and HER-2-negative patients. Actuarial overall survival rates were analysed by the Kaplan-Meier method and survival was measured in months 
from operation to death or last review. The log-rank test was applied to compare with the two groups. Univariate and multivariate survival analysis were calculated according to Cox's proportional-hazards model. All statistical analyses were performed using Statview 5.0 for Windows software and statistically significant difference was considered as $P$-values $<0.05$.

\section{RESULTS}

\section{Frequencies of HER-2 expression and gene amplification}

We studied 66 oesophageal SCC tumours and their regional lymph nodes. In IHC, each section was classified into four categories (negative, $1+, 2+, 3+$ ) according to the staining intensity scores provided by the HercepTest kit. Positive immunostaining $(1+I$ $2+/ 3+)$ of HER-2 expression was found in $20(30.3 \%)$ of the 66 patients with oesophageal SCC (Table 2). The clinicopathological data and their FISH analysis are summarised in Table 3. Three patients $(4.5 \%)$ showed strong positive staining $(3+)$ and $6(9.1 \%)$ showed moderate positive staining $(2+)$.

With respect to FISH, a cell was considered to show amplification when a definite cluster or more than 10 orange signals of HER-2 was observed in accordance with earlier studies with FISH (Takehana et al, 2002). In FISH analysis for IHC-positive oesophageal SCC $(n=20)$, HER-2 gene amplification (cluster,

Table 2 Frequencies of HER-2-positive patients detected by $I H C$ in oesophageal SCC

\begin{tabular}{lc}
\hline & Patients (total $=\mathbf{6 6})$ \\
\hline IHC scores & \\
$3+$ & $3(4.5 \%)$ \\
$2+$ & $6(9.1 \%)$ \\
$1+$ & $11(16.7 \%)$ \\
\hline
\end{tabular}

$\mathrm{IHC}=$ immunohistochemistry; SCC $=$ squamous cell carcinoma.
Figure 3) was found in seven tumours (Table 3). In the three tumours, cancer nuclei showed more than three HER-2 signals accompanied with the same number of centromere 17 signals. They were judged as polysomy 17 (Table 3 ).

With respect to the comparison of FISH and IHC analysis, all the strong positive $(3+)$ tumours were found to have gene amplification, as shown in Table 3. Among six moderate positive $(2+)$ tumours, three showed gene amplification (cluster) and one showed polysomy. In 11 weak positive $(1+)$ tumours, one showed gene amplification (cluster) and two showed polysomy.

Taken together, positive immunostaining $(1+/ 2+/ 3+)$ for HER-2 expression was found in $30.3 \%$. Moreover, moderate and strong positive patients $(2+/ 3+)$ had a high frequency of gene amplification, while weak positive $(1+)$ patients showed a low frequency of gene amplification.

\section{Immunostaining pattern and rate of HER-2-positive cells within each tumour}

When the clinical application of anti-HER-2 immune targeting is considered, it is important to clarify the heterogeneity in the pattern of HER-2-positive tumour cells within each tumour. According to the DAKO HercepTest kit, the grading of the HercepTest depends on the intensity of membranous staining, indicating that the grading does not reflect how many cells are HER-2 positive. Thus, in the present study, we evaluated the immunostaining pattern and rate of HER-2-positive cells within the tumour.

We recognised that there was heterogeneity in the pattern of HER-2 immunostaining and categorised the staining pattern into a spot type and diffuse type (Figure 2). Also, HER-2-positive cells were semiquantified by counting the average number in each tumour. As a result, all three strong positive $(3+)$ cases showed the diffuse-type pattern (Table 3 ) and had HER-2-positive cells in more than $30 \%$ of tumours (Table 4 ), while most of the weak positive $(1+)$ patients showed that HER-2-positive cells were less than $30 \%$ (Table 4$)\left(P=0.057, \chi^{2}\right.$ analysis). Thus, HER-2-positive

Table 3 Patients with HER-2-positive oesophageal SCC detected by $H \mathrm{HC}$ and their FISH analyses

\begin{tabular}{|c|c|c|c|c|c|c|c|c|}
\hline \multirow[b]{2}{*}{ Case number } & \multirow[b]{2}{*}{ Age (years) } & \multirow[b]{2}{*}{ Sex } & \multirow[b]{2}{*}{ Stage $^{a}$} & \multirow[b]{2}{*}{ Histological $^{\mathrm{b}}$ classification } & \multicolumn{3}{|c|}{ IHC } & \multirow[b]{2}{*}{ FISH } \\
\hline & & & & & Score ${ }^{c}$ & Pattern & Score $^{c}$ of LN & \\
\hline 1 & 73 & M & III & Mod & $3+$ & Diffuse & $3+$ & Cluster \\
\hline 2 & 54 & M & III & Por & $3+$ & Diffuse & $3+$ & Cluster \\
\hline 3 & 62 & M & $\mathrm{IVa}$ & Mod & $3+$ & Diffuse & $3+$ & Cluster \\
\hline 4 & 62 & M & $\mathrm{IVa}$ & Mod & $2+$ & Spot & 0 & Cluster \\
\hline 5 & 59 & M & III & Well & $2+$ & Diffuse & 0 & Cluster \\
\hline 6 & 57 & M & III & Mod & $2+$ & Spot & $2+$ & Polysomy \\
\hline 7 & 55 & M & $\|$ & Por & $2+$ & Diffuse & $2+$ & No amplification \\
\hline 8 & 69 & M & $\|$ & Well & $2+$ & Spot & No & No amplification \\
\hline 9 & 76 & M & I & Well & $2+$ & Spot & No & Cluster \\
\hline 10 & 56 & M & $\|$ & Mod & $1+$ & Spot & 0 & Polysomy \\
\hline 11 & 74 & M & III & Well & $1+$ & Diffuse & 0 & Polysomy \\
\hline 12 & 60 & M & III & Mod & $1+$ & Spot & 0 & No amplification \\
\hline 13 & 60 & M & III & Por & $1+$ & Diffuse & 0 & No amplification \\
\hline 14 & 64 & M & III & Mod & $1+$ & Diffuse & 0 & No amplification \\
\hline 15 & 67 & M & III & Mod & $1+$ & Diffuse & 0 & No amplification \\
\hline 16 & 71 & $M$ & III & Mod & $1+$ & Spot & 0 & No amplification \\
\hline 17 & 47 & $\mathrm{~F}$ & $\|$ & Por & $1+$ & Diffuse & $1+$ & No amplification \\
\hline 18 & 74 & M & 0 & Por & $1+$ & Spot & No & Cluster \\
\hline 19 & 70 & M & $\|$ & Mod & $1+$ & Diffuse & No & No amplification \\
\hline 20 & 80 & M & $\|$ & Por & $1+$ & Spot & No & No amplification \\
\hline
\end{tabular}

$\mathrm{SCC}=$ squamous cell carcinoma; $\mathrm{IHC}=$ immunohistochemistry; FISH = fluorescence in situ hybridisation; $\mathrm{LN}=$ lymph node; No = no lymph node metastasis. ${ }^{a}$ Stages were defined according to the TNM classification. ${ }^{b}$ Well = well-differentiated SCC; mod = moderately differentiated SCC; por = poorly differentiated SCC. ${ }^{\mathrm{I} I H C}$ score was defined by the staining intensity of tumour cells $(0,1+, 2+, 3+)$. 
cells were present more diffusely within each tumour in the HercepTest $3+$ patients than those who were HercepTest $1+$.

\section{Correlation of HER-2 expression in primary tumours and metastatic lymph nodes}

Of all 66 cohorts, 37 (56.1\%) had metastatic lymph nodes diagnosed by histopathological determination. While $15(75.0 \%)$
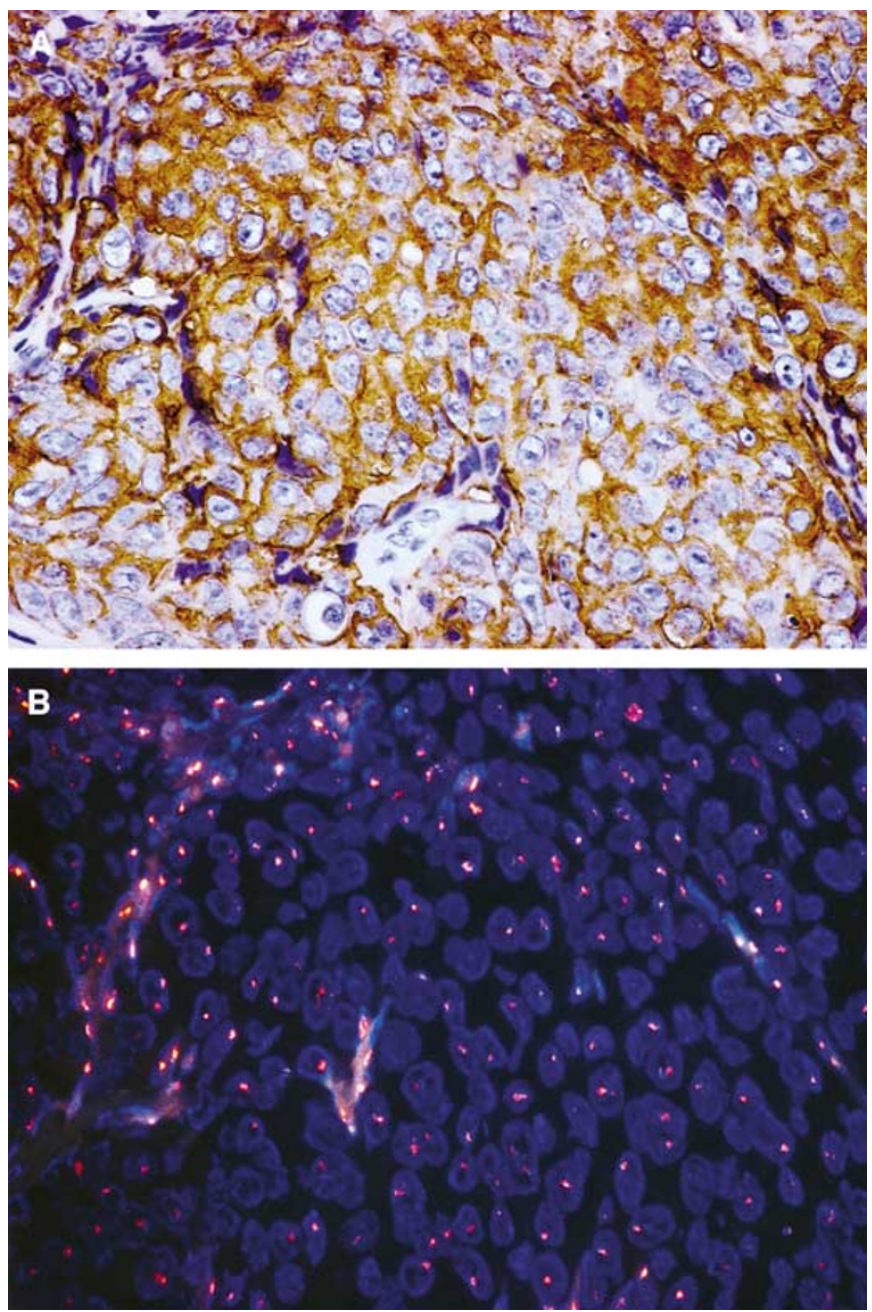

Figure 3 Representative FISH analysis of HER-2 gene amplification (cluster formation). The serial sections in the representative case were analysed by $\mathrm{IHC}(\mathbf{A})(3+$ staining cases, $\times 400)$ and FISH analysis $(\times 400$ in $(\mathbf{B})$ ).

Table 4 Correlation between IHC scores and the rate of HER-2-positive tumour cells in each tumour

\begin{tabular}{cccc}
\hline & \multicolumn{2}{c}{ Rate of HER-2/neu-positive cells in each section } \\
\cline { 2 - 4 } & $\sim \mathbf{3 0}(\%)$ & $\mathbf{3 1 - 6 0}(\%)$ & $\mathbf{6 I} \sim \mathbf{( \% )}$ \\
\hline$H C$ scores & & 2 & 1 \\
$3+(n=3)$ & 0 & 0 & 1 \\
$2+(n=6)$ & 5 & 1 & 2 \\
$1+(n=11)$ & 8 & $P=0.057$ by $\boldsymbol{\chi}^{2}$ test \\
\end{tabular}

$\mathrm{IHC}=$ immunohistochemistry in the 20 HER-2-positive patients had metastatic lymph nodes, 22 $(47.8 \%)$ in the 46 HER-2-negative patients had metastatic lymph nodes (Table 3 ), indicating that there was a high frequency of lymph node metastasis in the HER-2-positive patients in comparison to HER-2-negative patients $\left(P<0.05, \chi^{2}\right.$ analysis $)$. All the strongly positive $(3+)$ patients in the primary tumours were found to have HER-2-positive tumours $(3+)$ in the metastatic lymph nodes, while there was only one patient with a HER-2-positive tumour in the metastatic lymph node in the weak positive $(1+)$ patients with lymph node metastasis $(n=8)$.

\section{Frequency of the HLA haplotype relating to HER-2 status}

When anti-HER-2 immunotherapy such as cancer vaccination is considered for HER-2-positive patients, the candidates are restricted to a certain HLA haplotype (Kono et al, 2002a). It is important to clarify the HER-2 status relating to the HLA haplotype in patients with oesophageal SCC. In the patients tested for HLA haplotypes $(n=50)$, the distribution of the HLA-A haplotype in patients with oesophageal SCC is shown in Table 5. The most frequent HLA-A haplotypes in oesophageal SCC are HLA-A24 (64\%), HLA-A2 (52\%) and HLA-A11 (28\%). Also, oesophageal cancer patients with both HLA-A24-positive and HER-2-positive tumours accounted for $26 \%$ of these cases, and both HLA-A2-positive and HER-2-positive tumours accounted for $18 \%$ of them. There was no significant relation between the frequency of the HLA-A haplotype and the HER-2 status (Table 5).

\section{Analysis of the survival of patients with oesophageal SCC}

The survival rate in HER-2-positive $(1+/ 2+/ 3+)$ group was significantly worse than that in HER-2-negative group (Figure 4A). Moreover, there was a significant difference in the survival rate between HER-2 $(2+/ 3+)$ and HER-2-negative group (Figure $4 \mathrm{~B}$ ). The survival rate in the patients with HER-2 gene amplification was significantly worse than that without HER-2 gene amplification (Figure 5).

In univariate analysis, the factors such as HER-2 gene amplification, pT2 and pT3, lymph node metastasis, stages 3-4 were significant prognostic factors for survival (Table 6), although only pT2 factor reached to the significant level as independent risk factors for survival in multivariate analysis (Table 6).

Table 5 Frequencies of the HLA-A haplotype related to HER-2 expression in oesophageal SCC $(n=50)$

\begin{tabular}{|c|c|c|}
\hline & \multicolumn{2}{|c|}{ HER-2 status detected by IHC } \\
\hline & Positive $(n=18)$ & Negative $(n=32)$ \\
\hline \multicolumn{3}{|l|}{ HLA-A2 } \\
\hline Positive $(n=26)$ & $9(18 \%)^{a}$ & $17(34 \%)$ \\
\hline Negative $(n=24)$ & $9(18 \%)$ & $15(30 \%) N^{b}$ \\
\hline \multicolumn{3}{|l|}{ HLA-A I I } \\
\hline Positive $(n=14)$ & $7(14 \%)$ & $7(14 \%)$ \\
\hline Negative $(n=36)$ & 11 (22\%) & $25(50 \%)$ NS \\
\hline \multicolumn{3}{|l|}{ HLA-A24 } \\
\hline Positive $(n=32)$ & 13 (26\%) & 19 (38\%) \\
\hline Negative $(n=18)$ & $5(10 \%)$ & $13(26 \%)$ NS \\
\hline
\end{tabular}

British Journal of Cancer (2005) 92(7), $1253-1260$ 

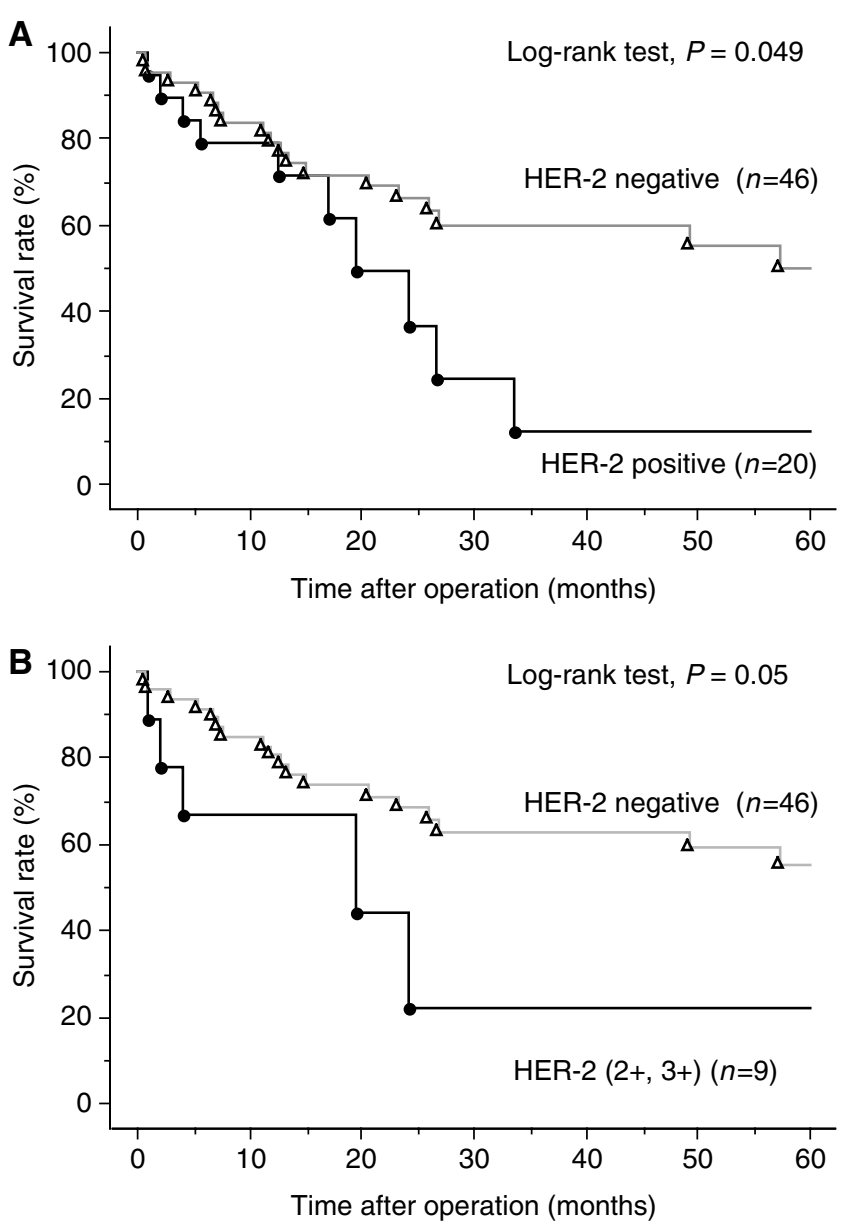

Figure 4 (A) Survival curves of HER-2-negative and HER-2-positive $(1+/ 2+13+)$ groups. (B) Survival curves of HER-2-negative and HER-2 $(2+/ 3+)$ groups.

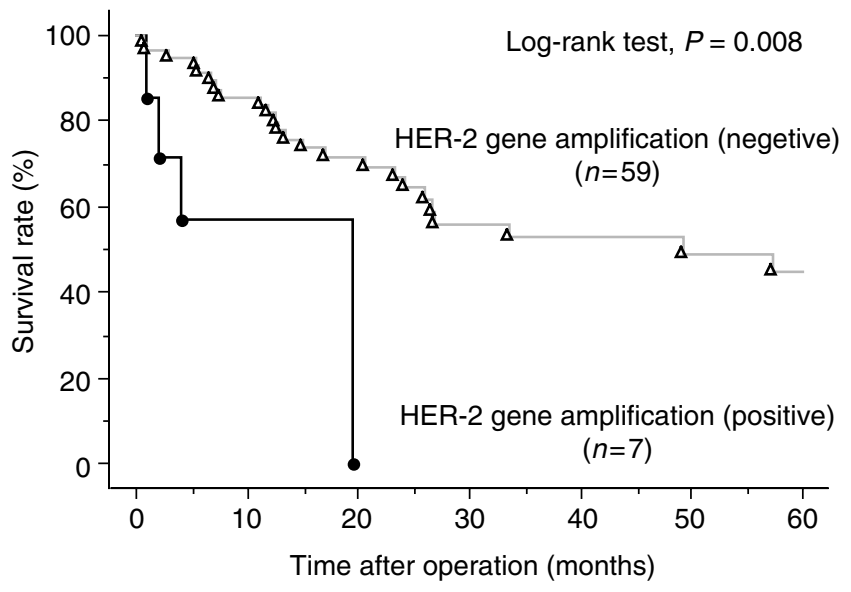

Figure 5 Survival curves of HER-2 gene amplification-negative and HER2 gene amplification-positive groups.

\section{DISCUSSION}

The present study contains several important findings relevant to HER-2 status in oesophageal SCC. First, HER-2-positive tumours $(1+/ 2+/ 3+)$ analysed by the HercepTest were observed in $30.3 \%$ of all patients and HER-2 gene amplification evaluated by FISH was observed in $11.0 \%$ of all patients, of which all IHC $(3+)$ tumours were found to have gene amplification and three out of six tumours with moderate positive $(2+)$ tumours showed gene amplification. Second, HER-2-positive cells existed more diffusely and were larger within each tumour in HercepTest $3+$ patients than those who were HercepTest $1+$. Thirdly, oesophageal SCC patients with both HLA-A24-and HER-2-positive tumours $(1+/$ $2+13+)$ accounted for $26 \%$ of these cases, and both HLA-A2- and HER-2-positive tumours accounted for $18 \%$ of them.

The frequencies of HER-2 overexpression in oesophageal SCC analysed by IHC ranged from 0 to $55.9 \%$ (Mori et al, 1987; Chang

Table 6 Significance of prognostic factors in univariate and multivariate survival analysis for patients with oesophageal SCC

\begin{tabular}{|c|c|c|c|c|c|c|}
\hline & \multicolumn{3}{|c|}{ Univariate analysis } & \multicolumn{3}{|c|}{ Multivariate analysis } \\
\hline & Hazard ratio & $95 \% \mathrm{Cl}$ & $P$-value & Hazard ratio & $95 \% \mathrm{Cl}$ & $P$-value \\
\hline \multicolumn{7}{|l|}{ FISH } \\
\hline Negative & 1.0 & - & - & 1.0 & - & - \\
\hline Positive & 4.05 & $1.31-12.53$ & 0.015 & 2.94 & $0.78-11.09$ & 0.111 \\
\hline \multicolumn{7}{|c|}{ HER-2 expression } \\
\hline \multicolumn{7}{|c|}{ Primary tumour ${ }^{\mathrm{a}}$} \\
\hline pTis-pTIb & 1.0 & - & - & 1.0 & - & - \\
\hline рT2 & 5.85 & $1.56-21.91$ & 0.009 & 5.00 & $1.06-23.52$ & 0.042 \\
\hline pT3 & 5.28 & $1.91-14.55$ & 0.001 & 3.01 & $0.76-11.95$ & 0.117 \\
\hline \multicolumn{7}{|l|}{ LNM } \\
\hline \multicolumn{7}{|l|}{ Stage $\mathrm{e}^{\mathrm{a}}$} \\
\hline $0-\|$ & 1.0 & - & - & 1.0 & - & - \\
\hline III-IV & 5.21 & $2.33-11.64$ & $<0.0001$ & 2.09 & $0.30-14.53$ & 0.458 \\
\hline
\end{tabular}

$\mathrm{SCC}=$ squamous cell carcinoma; $\mathrm{Cl}=$ confidence interval; $\mathrm{FISH}=$ fluorescence in situ hybridisation; $\mathrm{LNM}=$ lymph node metastasis. ${ }^{\mathrm{a}}$ The grade of tumour and stages were defined according to the UICC (TMN) classification. 
et al, 1992; Suo et al, 1992, 1995; Shiga et al, 1993; Suwanagool et al, 1993; Lam et al, 1998; Hardwick et al, 1997; Akamatsu et al, 2003). Furthermore, reports describing HER-2 gene amplification ranged from 0 to $25 \%$, in which these studies were performed by Northern blot, slot blot or RT-PCR analysis (Shiga et al, 1993; Ikeda et al, 1996; Tanaka et al, 1997; Friess et al, 1999). This is the first report describing the HER-2 status in oesophageal SCC analysed by two FDA-approved tests, the HercepTest and FISH (PathVysion test). Moreover, there was no previous report describing HER-2 status evaluated by the HercepTest and FISH in relation to the survival rate in oesophageal SCC. As a result, HER-2-positive tumours analysed by the HercepTest were observed in $30.3 \%$ of all the patients and HER-2 gene amplification evaluated by FISH was observed in $11.0 \%$ of all the patients.

There is increasing evidence that there is a discrepancy in the detection of HER-2 status between the two FDA-approved test, the HercepTest and FISH (PathVysion test), in which the concordance rates ranged from 80 to $90 \%$ (Jacobs et al, 1999; Varshney et al, 2004). There have been several reports that cases with HER-2 overexpression without gene amplification mostly occurred in moderate positive cases $(2+)$ (Perez et al, 2002; Varshney et al, 2004), in line with this study. Various explanations of this discrepancy have been proposed: transcriptional or post-translational activation (Slamon et al, 1989), artifactual high sensitivity of IHC (Varshney et al, 2004), the presence of chromosome 17 polysomy (Wang et al, 2002) or the low detection rate of FISH analysis (Jacobs et al, 1999). We found one case of polysomy in $2+$ patients and two cases of polysomy in $1+$ patients, suggesting that the presence of chromosome 17 polysomy might be one explanation for the discrepancy between the HercepTest and FISH in oesophageal SCC.

Interestingly, there was one case with HER-2 gene amplification in a HercepTest $1(+)$ tumour, indicating that the screening of HER-2 status by the HercepTest may underestimate HER-2 gene amplification. Since both the HercepTest and FISH assay have limitations in detecting HER-2 status, both methods should be applied when anti-HER-2 immune targeting, such as Herceptin or cancer vaccination, are considered in oesophageal SCC.

In this study, all the HercepTest $3+$ patients had HER-2 gene amplification, and HER-2-positive cells in these cases were present diffusely and were larger within the tumours. Furthermore, the HER-2 expression in HercepTest $3+$ patients was also preserved in the metastatic lymph nodes. The action of anti-HER-2-specific CTL correlated to the degree of HER-2 expression on the target tumour cells (Fisk et al, 1995; Kono et al, 1998). Also, the activity of ADCC induced by Herceptin correlated to the degree of HER-2 expression on the target tumour cells (Kono et al, 2002b). These results indicate that HercepTest $3+$ patients in oesophageal SCC will be the best candidates for anti-HER-2 immune targeting. It has already been shown in breast cancer trials that there is a greater benefit from Herceptin therapy for $3+$ patients compared to those who were $2+$ (Cobleigh et al, 1999; Slamon et al, 2001).

The survival rate in patients with HER-2 expression or HER-2 gene amplification was significantly worse than that without HER2 expression or HER-2 gene amplification. These results indicated that HER-2 status may be one of the prognostic factors to predict the clinical course of patients with oesophageal SCC, although the HER-2 status did not reach to the significant level as independent risk factors for survival in multivariate analysis in the present study. Since the sample size of the present study is limited, further studies with larger cohorts will be needed to draw valid conclusion.

When considering the cancer vaccination with HER-2-derived peptide epitopes, there is an HLA restriction. It has been shown that HLA-A2- or HLA-A24-restricted peptide epitopes were identified for immunodominant CTL epitopes derived from HER-2 (Fisk et al, 1995; Kono et al, 1998, 2002b). In the present study, oesophageal SCC patients with both HLA-A24- and HER-2positive tumours $(1+/ 2+/ 3+)$ accounted for $26 \%$ of these cases, and both HLA-A2- and HER-2-positive tumours accounted for $18 \%$ of them. These populations are considered for cancer vaccination with the HER-2 peptide in oesophageal SCC. In fact, we and others reported that clinical vaccination trials in gastric or breast cancer patients using DCs pulsed with HER-2 peptides confirmed the fact that vaccination with HER-2 peptides is immunogenic, and that HER-2 could be a good target for immunotherapy (Disis et al, 1999; Kono et al, 2002c). Furthermore, we have recently shown that Herceptin enhances MHC class Irestricted antigen presentation in HER-2-overexpressing tumours, resulting in a higher susceptibility of HER-2-overexpressing tumours to lysis by HER-2-specific CTL (Kono et al, 2004). These results suggested that the combination of Herceptin and anti-HER2-specific CTLs may result in a synergic antitumour effect in oesophageal SCC. Anti-HER-2 immune targeting such as Herceptin or cancer vaccination with HER-2 peptides is novel and attractive approach for oesophageal SCC and the candidates for HER-2based immunotherapy were limited, but significant populations of oesophageal SCC.

\section{ACKNOWLEDGEMENTS}

This work was supported by a grant from the Ministry of Education, Culture, Sports, Science and Technology in Japan and from the Japanese Foundation for Multidisciplinary Treatment of Cancer.

\section{REFERENCES}

Adham M, Baulieux J, Mornex F, de La Roche de Bransat E, Ducerf C, Souquet JC, Gerard JP (2000) Combined chemotherapy and radiotherapy followed by surgery in the treatment of patients with squamous cell carcinoma of the esophagus. Cancer 89: 946-954

Akamatsu M, Matsumoto T, Oka K, Yamasaki S, Sonoue H, Kajiyama Y, Tsurumaru M, Sasaki K (2003) C-erbB-2 oncoprotein expression related to chemoradioresistance in esophageal squamous cell carcinoma. Int $J$ Radiat Oncol Biol Phys 57: 1323-1327

Akiyama H, Turumaru M, Udagawa H, Kajiyama Y (1994) Radical lymph node dissection for cancer of the thoracic esophagus. Ann Surg 220: $364-372$

Altorki NK, Skinner DB (1990) En bloc esophagectomy: the first 100 patients. Hepatogastroenterology 37: 360-363

Baselga J, Tripathy D, Mendelsohn J, Baughman S, Benz CC, Dantis L, Sklarin NT, Seidman AD, Hudis CA, Moore J, Rosen PP, Twaddell T, Henderson IC, Norton L (1996) Phase II study of weekly intravenous

recombinant humanized anti-p185HER2 monoclonal antibody in patients with HER2/neu-overexpressing metastatic breast cancer. J Clin Oncol 14: $737-744$

Chang K, Pastan I, Willingham MC (1992) Frequent expression of the tumour antigen CAKI in squamous cell carcinomas. Int J Cancer 51: $548-554$

Cobleigh MA, Vogel CL, Tripathy D, Robert NJ, Scholl S, Fehrenbacher L, Wolter JM, Paton V, Shak S, Lieberman G, Slamon DJ (1999) Multinational study of the efficacy and safety of humanized anti-HER2 monoclonal antibody in women who have HER2-overexpressing metastatic breast cancer that has progressed after chemotherapy for metastatic disease. J Clin Oncol 17: 2639-2648

Coussens L, Yang-Feng TL, Liao YC, Chen E, Gray A, McGrath J, Seeburg PH, Libermann TA, Schlessinger J, Francke U (1985) Tyrosine kinase receptor with extensive homology to EGF receptor shares chromosomal location with neu oncogene. Science 230: 1132-1139 
Disis ML, Grabstein KH, Sleath PR, Cheever MA (1999) Generation of immunity to the HER-2/neu oncogenic protein in patients with breast and ovarian cancer using a peptides-base vaccine. Clin Cancer Res 5: $1289-1297$

Fisk B, Blevins TL, Wharton JT, Ioannides CG (1995) Identification of an immunodominant peptide of HER-2/neu protooncogene recognized by ovarian tumor-specific cytotoxic T lymphocyte line. J Exp Med 181: 2109-2117

Friess H, Fukuda A, Tang WH, Eichenberger A, Furlan N, Zimmermann A, Korc M, Buchler MW (1999) Concomitant analysis of the epidermal growth factor receptor family in esophageal cancer: overexpression of epidermal growth factor receptor mRNA but not of c-erbB-2 and c-erbB3. World J Surg 23: $1010-1018$

Hardwick RH, Barham CP, Ozua P, Newcomb PV, Savage P, Powell R, Rahamin J, Alderson D (1997) Immunohistochemical detection of p53 and c-erbB-2 in oesophageal carcinoma; no correlation with prognosis. Eur J Surg Oncol 23: 30-35

Hayashi K, Ando N, Watanabe H, Ide H, Nagai K, Aoyama N, Takiyama W, Ishida $\mathrm{K}$, Isono $\mathrm{K}$, Makuuchi $\mathrm{H}$, Imamura $\mathrm{M}$, Shinoda $\mathrm{M}$, Ikeuchi S, Kabuto T, Yamana H, Fukuda H (2001) Phase II evaluation of protracted infusion of cisplatin and 5-fluorouracil in advanced squamous cell carcinoma of the esophagus: a Japan Esophageal Oncology Group (JEOG) Trial (JCOG9407). Jpn J Clin Oncol 31: 419-423

Ikeda Y, Ozawa S, Ando N, Kitagawa Y, Ueda M, Kitajima M (1996) Meaning of $\mathrm{c}$-erbB and int-2 amplification in superficial esophageal squamous cell carcinomas. Ann Thorac Surg 62: 835-838

Ishikura S, Nihei K, Ohtsu A, Boku N, Hironaka S, Mera K, Muto M, Ogino T, Yoshida S (2003) Long-term toxicity after definitive chemoradiotherapy for squamous cell carcinoma of the thoracic esophagus. J Clin Oncol 21: $2697-2702$

Jacobs TW, Gown AM, Yaziji H, Barnes MJ, Schnitt SJ (1999) Comparison of fluorescence in situ hybridization and immunohistochemistry for the evaluation of HER-2/neu in breast cancer. J Clin Oncol 17: $1974-1982$

Kato H, Watanabe H, Tachimori Y, Iizuka T (1991) Evaluation of neck lymph node dissection for thoracic esophageal carcinoma. Ann Thorac Surg 51: $931-935$

Kono K, Rongcun Y, Charo J, Ichihara F, Celis E, Sette A, Apella E, Sekikawa T, Matsumoto Y, Kiessling R (1998) Identification of HER2/ neu-derived peptide epitopes recognized by gastric cancer-specific CTLs. Int J Cancer 78: $202-208$

Kono K, Sato E, Naganuma H, Takahashi A, Mimura K, Nukui H, Fujii H (2004) Trastuzumab (Herceptin) enhances class I-restricted antigen presentation recognized by HER-2/neu-specific T cytotoxic lymphocytes. Clin Cancer Res 10: $2538-2544$

Kono K, Takahashi A, Amemiya H, Ichihara F, Sugai H, Iizuka H, Fujii H, Matsumoto Y (2002a) Frequencies of HER-2/neu overexpression relating to HLA haplotype in patients with gastric cancer. Int $J$ Cancer 98: $216-220$

Kono K, Takahashi A, Ichihara F, Sugai H, Fujii H, Matsumoto Y (2002b) Impaired antibody-dependent cellular cytotoxicity mediated by herceptin in patients with gastric cancer. Cancer Res 62: 5813-5817

Kono K, Takahashi A, Sugai H, Fujii H, Choudhury AR, Kiessling R, Matsumoto Y (2002c) Dendritic cells pulsed with HER-2/neu-derived peptides can induce specific T-cell responses in patients with gastric cancer. Clin Cancer Res 8: $3394-3400$

Lam KY, Tin L, Ma L (1998) C-erbB-2 protein expression in oesophageal squamous epithelium from oesophageal squamous cell carcinomas, with special reference to histological grade of carcinoma and pre-invasive lesions. Eur J Surg Oncol 24: $431-435$
Le Prise EA, Meunier BC, Etienne PL, Julienne VC, Gedouin DM, Raoul JL, Ben Hassel M, Campion JP, Launois B (1995) Sequential chemotherapy and radiotherapy for patients with squamous cell carcinoma of the esophagus. Cancer 75: 430-434

Maillet P, Baulieux J, Boulez J, Benhaim R (1982) Carcinoma of the esophagus. Results of one stage surgery (271 cases). Am J Surg 143: $629-634$

Mori S, Akiyama T, Morishita Y, Shimizu S, Sakai K, Sudoh K, Toyoshima K, Yamamoto T (1987) Light and electron microscopical demonstration of c-erbB-2 gene product like immunoreactivity in human malignant tumors. Virchows Arch B Cell Pathol Incl Mol Pathol 54: 8-15

Perez EA, Roche PC, Jenkins RB, Reynolds CA, Halling KC, Ingle JN, Wold LE (2002) HER2 testing in patients with breast cancer: poor correlation between weak positivity by immunohistochemistry and gene amplification by fluorescence in situ hybridization. Mayo Clin Proc 77: 148-154

Popescu NC, King CR, Kraus MH (1989) Localization of the human erbB-2 gene on normal and rearranged chromosomes 17 to bands q12-21.32. Genomics 4: $362-366$

Shiga K, Shiga C, Sasano H, Miyazaki S, Yamamoto T, Yamamoto M, Hayashi N, Nishihira T, Mori S (1993) Expression of c-erbB-2 in human esophageal carcinoma cells: overexpression correlated with gene amplification or with GATA-3 transcription factor expression. Anticancer Res 13: $1293-1301$

Slamon DJ, Godolphin W, Jones LA, Holt JA, Wong SG, Keith DE, Levin WJ, Stuart SG, Udove J, Ullrich A (1989) Studies of the HER-2/neu protooncogene in human breast and ovarian cancer. Science 244: 707-712

Slamon DJ, Leyland-Jones B, Shak S, Fuchs H, Paton V, Bajamonde A, Fleming T, Eiermann W, Wolter J, Pegram M, Baselga J, Norton L (2001) Use of chemotherapy plus a monoclonal antibody against HER2 for metastatic breast cancer that overexpress HER2. $N$ Engl J Med 344: $783-792$

Sliwkowski MX, Lofgren JA, Lewis GD, Hotaling TE, Fendly BM, Fox JA (1999) Nonclinical studies addressing the mechanism of action of Trastuzumab (Herceptin). Semi Oncol 26: 60-70

Suo Z, Holm R, Nesland JM (1992) Squamous cell carcinomas, an immunohistochemical and ultrastructural study. Anticancer Res 12: $2025-2031$

Suo Z, Su W, Holm R, Nesland JM (1995) Lack of expression of c-erbB-2 oncoprotein in human esophageal squamous cell carcinomas. Anticancer Res 15: $2797-2798$

Suwanagool P, Parichatikanond P, Maeda S (1993) Expression of c-erbB-2 oncoprotein in primary human tumors: an immunohistochemistry study. Asian Pac J Allergy Immunol 11: 119-122

Takehana T, Kunitomo K, Kono K, Kitahara F, Iizuka H, Matsumoto Y, Fujino M, Ooi A (2002) Status of c-erbB-2 in gastric adenocarcinoma: a comparative study of immunohistochemistry, fluorescence in situ hybridization and enzyme-linked immuno-sorbent assay. Int $J$ Cancer 98: $833-837$

Tanaka S, Mori M, Akiyoshi T, Tanaka Y, Mafune K, Wands JR, Sugimachi K (1997) Coexpression of Grb7 with epidermal growth factor receptor or Her2/erbB2 in human advanced esophageal carcinoma. Cancer Res 57: 28-31

Varshney D, Zhou YY, Geller SA, Alsabeh R (2004) Determination of HER-2 status and chromosome 17 polysomy in breast carcinomas comparing Hercep Test and PathVysion FISH assay. Am J Clin Pathol 121: $70-77$

Wang S, Hossein Saboorian M, Frenkel EP, Haley BB, Siddiqui MT, Gokaslan S, Hynan L, Ashfaq R (2002) Aneusomy 17 in breast cancer: its role in HER-2/neu protein expression and implication for clinical assessment of HER-2/neu status. Mod Pathol 15: 137-145 